\section{High Glucose Affects Proliferation, Reactive Oxygen Species and Mineralization of Human Dental Pulp Cells}

Sivaporn Horsophonphong ${ }^{1} \mathbb{D}$, Nakarin Kitkumthorn ${ }^{1} \mathbb{D}$, Hathaitip Sritanaudomchai ${ }^{1}$, Siriruk Nakornchai ${ }^{2}{ }^{\circledR}$, Rudee Surarit ${ }^{1}$ (i)

\author{
'Department of Oral Biology, \\ Faculty of Dentistry, Mahidol \\ University, Thailand \\ ${ }^{2}$ Department of Pediatric \\ Dentistry, Faculty of Dentistry, \\ Mahidol University, Thailand \\ Correspondence: Rudee Surarit, \\ Yothi Road, 6 10400, Bangkok, \\ Thailand. Tel: +66-2-2007993. \\ e-mail: rudee.sur@mahidol.ac.th
}

Diabetes is a group of metabolic disorders that can lead to damage and dysfunction of many organs including the dental pulp. Increased inflammatory response, reduction of dentin formation and impaired healing were reported in diabetic dental pulp. Hyperglycemia, which is a main characteristic of diabetes, was suggested to play a role in many diabetic complications. Therefore our aim was to investigate the effects of high glucose levels on proliferation, reactive oxygen species (ROS) production and odontogenic differentiation of human dental pulp cells (HDPCs). HDPCs were cultured under low glucose $(5.5 \mathrm{mM}$ Glucose), high glucose ( $25 \mathrm{mM}$ Glucose) and mannitol (iso-osmolar control) conditions. Cell proliferation was analyzed by MTT assay for 11 days. Glutathione and DCFH-DA assay were used to assess ROS and antioxidant levels after $24 \mathrm{~h}$ of glucose exposure. Odontogenic differentiation was evaluated and quantified by alizarin red staining on day 21. Expression of mineralization-associated genes, which were alkaline phosphatase, dentin sialophosphoprotein and osteonectin, was determined by RT-qPCR on day 14 . The results showed that high glucose concentration decreased proliferation of HDPCs. Odontogenic differentiation, both by gene expression and mineral matrix deposit, was inhibited by high glucose condition. In addition, high DCF levels and low reduced glutathione levels were observed in high glucose condition. However, no differences were observed between mannitol and low glucose conditions. In conclusion, the results clearly showed the negative effect of high glucose condition on HDPCs proliferation and differentiation. Moreover, it also induced ROS production of HDPCs.
Key Words: high glucose, diabetes, human dental pulp cells, reactive oxygen species, odontogenic differentiation.

\section{Introduction}

Dental pulp is a soft connective tissue located inside the tooth. The outer most layer of dental pulp consists of odontoblasts. The main function of odontoblasts is to create dentin surrounding the dental pulp (1). Dentin is formed during tooth development and continues to form throughout life. During tooth injuries, such as dental caries, trauma and inflammation, new odontoblasts are regenerated from dental pulp progenitor cells and subsequently dentine will be reformed $(1,2)$. Dental pulp is also proven to be affected by diabetes which is a group of metabolic disorders characterized by abnormally high blood glucose levels or hyperglycemia (3). Hyperglycemia can induce the production of reactive oxygen species (ROS) and impaired antioxidant defenses that may lead to many diabetic complications (4). Several studies reported alterations and complications in diabetic dental pulp (59). Changes in dental pulp structure and its components, narrow pulp capacity and changes in pulpal vasculature were observed in diabetic individuals $(5,8,10)$. An increase in inflammatory cells infiltration and higher expression of inflammatory mediators were reported in diabetic dental pulp $(5,6)$. Reactive oxygen species production (ROS) and oxidative stress were observed in dental pulp of diabetic rats $(5,7)$. Dental pulp of diabetic individuals was reported to be susceptible to bacterial infiltration and infection leading to irreversible pulpitis, pulp necrosis and subsequently periapical lesions (9). Moreover, impaired dentin formation and pulpal healing were reported in diabetic dental pulp due to the inhibition of dentin bridge formation, lower expression of dentinogenesis molecules and thickened predentin layer leading to reduction of healing process $(6,10)$.

Recently, it was reported that there were an increase in inflammatory responses and a decrease in mineral bone formation, when bone marrow stem cells and osteoblast cells were cultured under high glucose conditions. However, few studies have investigated the effects of high level of glucose on human dental pulp cells (HDPCs) and presently there is still controversy on the results $(11,12)$.

Due to the facts that diabetes caused many complications in dental pulp and high level of glucose, which is a major characteristic of diabetes, was suggested to be the main factor causing diabetic complications. Therefore, this study performed an in vitro investigation with an aim of investigating the effects of high glucose 
level on proliferation, ROS production and odontogenic differentiation of HDPCs. The null hypothesis was that high glucose level should have no effect on HDPCs.

\section{Material and Methods}

Isolation and Culture of HDPCs

HDPCs were collected from non-carious human third molars, obtained from six healthy donors (aged 18-30 years), who signed informed consent, at the Faculty of Dentistry, Mahidol University, Thailand. The project was approved by the Ethical committee of the Faculty of Dentistry and Pharmacy, Mahidol University (COE: No.MU-DT/PY-IRB 2017/011.3103). The tissue explant technique was used for HDPCs (13). In short, a groove was made along the cementoenamel junction by a diamond fissure bur with constant irrigation. Then, teeth were split and pulp tissues were obtained. Pulp tissues were minced into $0.5-1 \mathrm{~mm}^{2}$ fragments and cultured in $5.5 \mathrm{mM}$ D-glucose Dulbecco's Modified Eagle Medium (DMEM; HyClone, Logan, UT, USA) supplemented with 10\% fetal bovine serum (FBS; HyClone) and 1\% penicillin-streptomycin (Pen-Strep, Gibco, Grand Island, NY, USA), and incubated at $37{ }^{\circ} \mathrm{C}$ in humidified atmosphere containing $5 \% \mathrm{CO}_{2}$. The medium was changed every 3 days. When the outgrowth of cells reached 80\% confluence, cells were trypsinized and subcultured. Cells between passages $4^{\text {th }}-6^{\text {th }}$ were used in this study.

\section{Cell Proliferation Assay}

HDPCs were maintained in $5.5 \mathrm{mM}$ D-glucose DMEM supplemented with 10\% FBS and 1\% Pen-Strep (from now on referred to as standard culture medium). Treatment conditions consisted of: 1) DMEM with 5.5mM-D glucose (from now on referred to as low glucose; LG), 2) DMEM with $25 \mathrm{mM}$ D-glucose (from now on referred to as high glucose; $\mathrm{HG}$ ), and 3) DMEM with $5.5 \mathrm{mM}$ D-glucose and 19.5mM D-mannitol (Merck, Darmstadt, Germany) (from now on referred to as mannitol; Man). Then the cell viability was determined on day $1,3,5,9,11$ using thiazoyl blue tetrazolium bromide (MTT; Sigma-Aldrich, St. Louis, MO, USA). The assay was performed according to the procedure describe previous by Mosmann (14). The absorbance at $570 \mathrm{~nm}$ was measured using microplate reader (Synergy H1, BioTek, Winooski, VT, USA). Cell numbers were calculated based on a standard curve.

\section{2,7-Dichlorodihydrofluorescein Diacetate} (DCFH-DA) Assay: Analysis of Cellular ROS Production

Analysis of cells treated with DCFH-DA (SigmaAldrich) was used to measure ROS production (15). Cells were seeded into 96-well black plates at a density of $1 \times 10^{4}$ cells/well in standard culture medium, and allowed to adhere overnight. Then the medium was changed to serum free medium and incubated for further $24 \mathrm{~h}$. After that, cells were cultured under six conditions: $\mathrm{LG}, \mathrm{HG}$, and Man-all either with or without odontogenic inducers (OI). The Ol consist of $50 \mu \mathrm{g} / \mathrm{mL}$ ascorbic acid (Sigma-Aldrich), $10 \mathrm{mM} \beta$-glycerophosphate (Sigma-Aldrich) and $100 \mathrm{nM}$ dextamethasone (Sigma-Aldrich). After treatment for 24 $\mathrm{h}$, cells were treated with $100 \mu \mathrm{M}$ of DCFH-DA and the fluorescence intensity of dichlorofluorescein (DCF) was measured by microplate reader (Synergy H1, BioTek) at an excitation wavelength of $485 \mathrm{~nm}$ and emission wavelength of $535 \mathrm{~nm}$. The fluorescence intensity of DCF was analyzed and reported as percent of $L G$, which was set to $100 \%$.

\section{GSH Assay: Analysis of Cellular Antioxidant Defense}

Reduced glutathione (GSH) was measured using the Glutathione Assay Kit (Sigma-Aldrich). The assay was performed according to the manufacturer's instructions. Briefly, cells were cultured under different treatment conditions which were $\mathrm{LG}, \mathrm{HG}$ and Man for $24 \mathrm{~h}$. Cells were scraped and lysed with lysis buffer, and then centrifuged. The supernatant was transferred to black microplate followed by the addition of Glutathione S-Transferase (GST) and substrate (monochlorobimane). Then, the fluorescence intensity was measured at an excitation wavelength of 390 $\mathrm{nm}$ and emission wavelength of $478 \mathrm{~nm}$. The GSH levels were further normalized against total protein concentrations. The protein concentrations were measured with $\mathrm{BCA}$ Protein Assay Kit (Pierce, Rockville, IL, USA), following the manufacturer's instructions.

\section{Mineralization Assay and Quantification of Mineral Matrix Formation}

HDPCs were cultured with odontogenic medium which consisted of $\mathrm{Ol}$ and supplemented with 10\% FBS and 1\% Pen-Strep at various conditions which were $L G, H G$ and Man. The medium was replaced every 3 days. After culturing for 21 days, the cells were fixed with $70 \%$ ethanol then

Table 1. Primer sequence

\begin{tabular}{cccc}
\hline Genes & GeneBank No. & Sequences (5'-3') & $\begin{array}{c}\text { Product } \\
\text { size (BP) }\end{array}$ \\
\hline ALP & NM_001177520.2 & $\begin{array}{l}\text { F: CCTATTGGGTCTCTTCGAGCC } \\
\text { R: CCACGGTCAGAGTGTCTTCC }\end{array}$ & 269 \\
DSPP & NM_014208.3 & $\begin{array}{l}\text { F: CAGGACCATGGGAAAGAAGATG } \\
\text { R: TCTATTCCCTTATCTTGGCTCTTCC }\end{array}$ & 284 \\
& & F: CTGGACTACATCGGGCCTTG & 174 \\
ON & NM_003118.3 & R: ATGGATCTTCTTCACCCGCA & 174 \\
& & F: AAAGTAGTCCCTTCTCGGCG & 175 \\
UBC & NM_021009.6 & R: CACGAAGATCTGCATTGTCAAG & 175 \\
\hline
\end{tabular}


stained with $40 \mathrm{mM}$ alizarin red S (ARS; Sigma-Aldrich) at room temperature. The ARS-calcium complexes were further quantified by extraction with 10\% (v/v) acetic acid, and the absorbance were measured at $405 \mathrm{~nm}$, as described by Gregory et al. (16).

\section{mRNA Isolation and Reverse Transcription Quantitative (Real-Time) Polymerase Chain Reaction (RT-qPCR)}

After culturing for 14 days, RNA was isolated using TRIzol reagent (Invitrogen, Carlsbad, CA, USA). After that $1 \mu \mathrm{g}$ of total RNA was reverse-transcribed into cDNA using RevertAid First Strand cDNA Synthesis Kit (Thermo Fisher Scientific). Real-time PCR was performed with StepOnePlus Real-Time PCR System (Applied Biosystems, Foster City, CA, USA) using KAPA SYBR FAST qPCR Master Mix (Sigma-Aldrich) for detection of mineralizationassociated genes which were Alkaline phosphatase (ALP), Dentin sialophosphoprotein (DSPP) and Osteonectin (ON). Thermocycling conditions consisted of $95{ }^{\circ} \mathrm{C}$ for $5 \mathrm{~min}$ followed by 40 cycles of denaturing at $95{ }^{\circ} \mathrm{C}$ for $15 \mathrm{~s}$, annealing at $60{ }^{\circ} \mathrm{C}$ for $30 \mathrm{~s}$ and extension at $72{ }^{\circ} \mathrm{C}$ for $25 \mathrm{~s}$. Relative gene expressions were analyzed using $\triangle \Delta C T$ method and Ubiquitin C (UBC) was used as a reference gene. The primer sequences were described in Table 1.

\section{Statistical Analysis}

At least three independent experiments were performed and each experiment was also performed with the minimum of three replicates. Statistical analysis was performed using SPSS version 18 (IBM, Armonk, NY, USA). The differences between three or more groups were analyzed by one-way ANOVA followed by Tukey's HSD or Games-Howell post hoc test, and differences between two groups were analyzed by independent samples t-test. A p-value of less than $0.05(p<0.05)$ was considered statistical significant.

\section{Results}

\section{Cell Proliferation}

HG exhibited inhibitory effect on cell proliferation, as shown in Figure 1. On days 9 and 11 significant differences were observed between LG and $\mathrm{HG}$, as well as between Man and HG $(p<0.05$, Fig. 1).

\section{ROS Production and GSH Levels}

HG significantly increased DCF levels when compared between groups $(\mathrm{p}<0.05)$ to Man and $L G$, whereas no differences were observed between Man and LG ( $p<0.05$, Fig. 2A). Moreover, HG significantly decreased GSH levels when compared to both Man and LG ( $p<0.05$, Fig. 2B). Furthermore, when Man, $\mathrm{LG}$ and $\mathrm{HG}$ were supplemented with OI, no differences in DCF levels were noted between these three groups (data not shown).

\section{mRNA Expression of Mineralization Associated Genes}

The relative mRNA expression of $L G$ compared to $H G$ showed significantly higher expression of mineralizationassociated genes, namely alkaline phosphatase (ALP), dentin sialophosphoprotein (DSPP) and osteonectin (ON) ( $p<0.05$, Fig. 3).

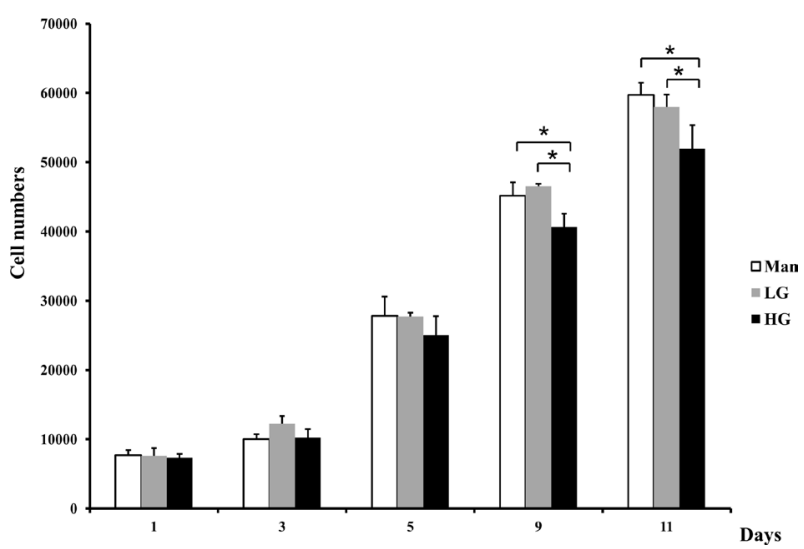

Figure 1. Proliferation of HDPCs. Cells were cultured for 1, 3, 5, 9, 11 days, on day 9 and day 11 significant differences were observed between LG and HG as well as between Man and HG. Low glucose (LG), High glucose (HG) and Mannitol (Man). * indicates a statistically significant difference between groups $(\mathrm{p}<0.05)$
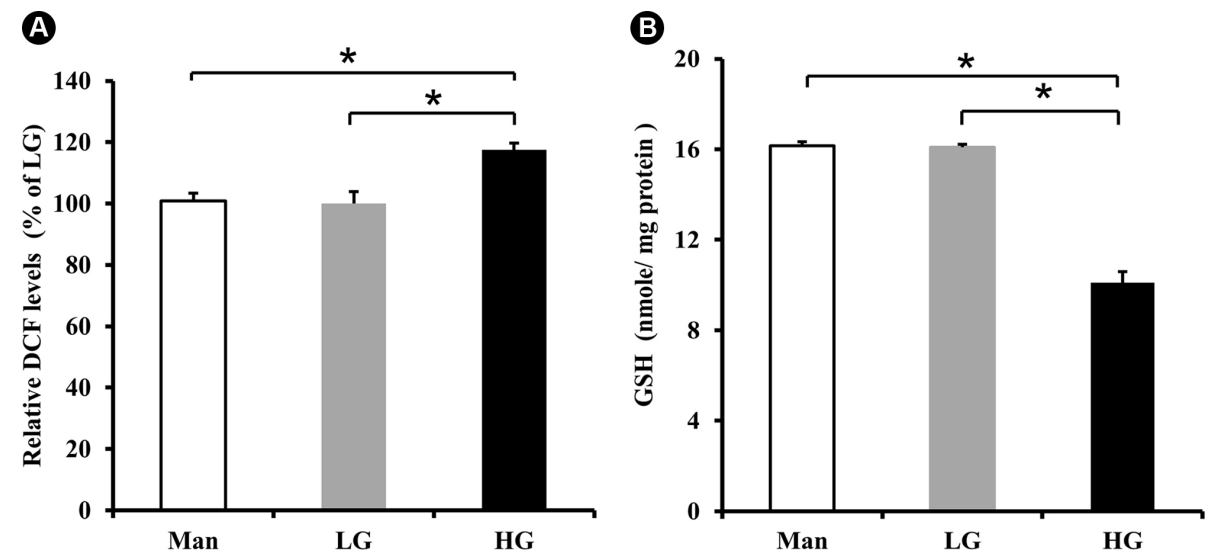

Figure 2. ROS and GSH levels of HDPCs. A: Quantitative ROS production was determined by DCF levels relative to LG, significant differences were noted between LG and HG as well as between Man and HG. B: GSH levels representing cellular antioxidant defense, significant differences were noted between LG and HG as well as between Man and HG. Low glucose (LG), High glucose (HG), Mannitol (Man), Dichlorofluorescein (DCF) and Glutathione (GSH). * indicates a statistically significant difference 


\section{Mineralization of HDPCs}

On day $21, \mathrm{HG}$ condition clearly inhibited formation of mineralized nodules, as shown in Fig. 4A and B. Moreover, quantification of ARS indicated that $\mathrm{HG}$ exhibited significantly lower ARS concentration when compared to LG and Man ( $p<0.05$, Fig. 4 C).

\section{Discussion}

Dentin-pulp complex plays an important role in the function and survival of the tooth. Unlike enamel, which

is only formed during tooth development, dentin can be synthesized by odontoblast cells throughout life, as long as the tooth remains vital $(1,17)$. Tooth injury such as dental caries, trauma, or cavity preparation can cause inflammation and invasion of microorganisms along the dentinal tubule. In response to low grade inflammation, tertiary dentin is synthesized by pre-existing odontoblasts, located at the outer-most of the pulp. However, more intense inflammation can destroy the pre-existing odontoblasts, causing pulpal mesenchymal cells to differentiate into odontoblast-like-cells and secrete dentin (17). Therefore, it is crucial to maintain the functions of dental pulp.

Diabetes is a metabolic
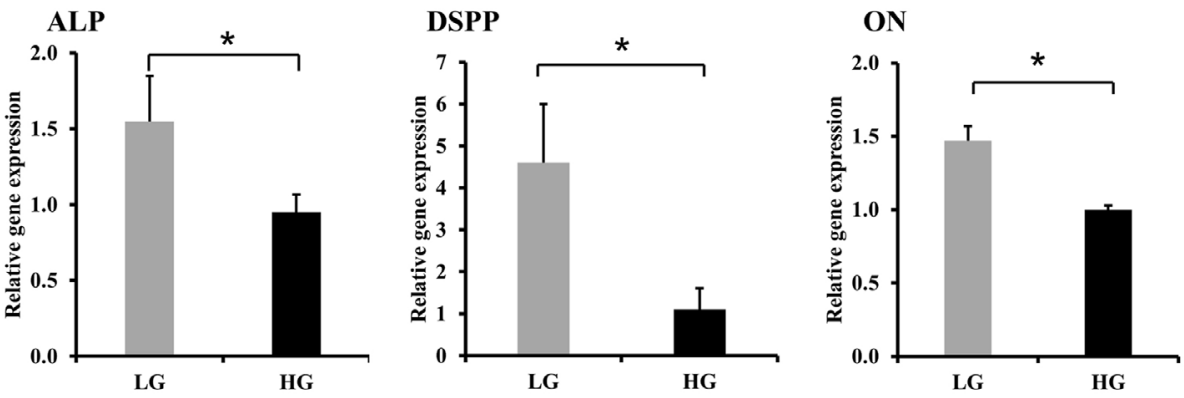

Figure 3. The expression of mineralization-associated genes: ALP, DSPP and ON, after 14 days of odontogenic induction. HG significantly increased the expression of mineralization-associated genes. Low glucose (LG) and High glucose (HG), Alkaline phosphatase (ALP), Dentin sialophosphoprotein (DSPP) and Osteonectin (ON). * indicates a statistically significant difference between groups $(\mathrm{p}<0.05)$

A

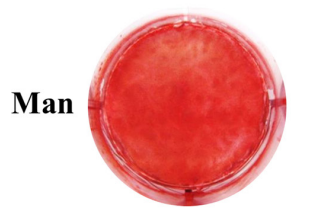

LG

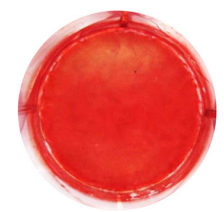

HG

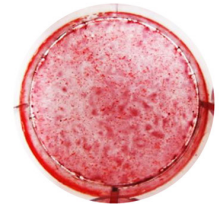

B
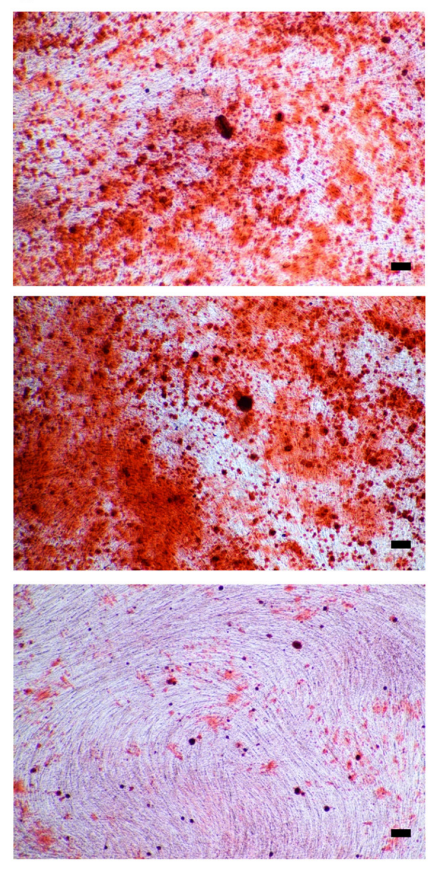

C

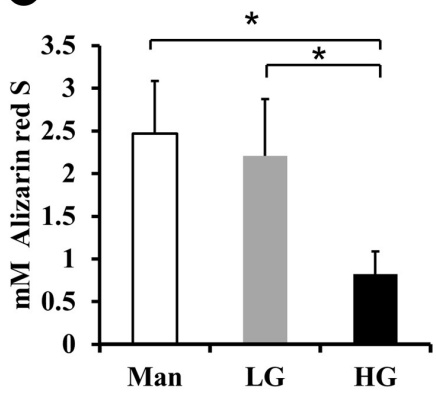

Figure 4. Mineralization of HDPCs after 21 days of odontogenic induction. A: The calcified matrix was assessed by ARS staining, B: original magnification 40×, dark spot indicated mineral nodule formation. Scale bars $=100 \mu \mathrm{m}$. C: Quantification of ARS - mineral complex, significant differences were observed between LG and HG as well as between Man and HG. Low glucose (LG), High glucose (HG) and Mannitol (Man). * indicates statistically significant difference between groups $(\mathrm{p}<0.05)$ disease that associated with damage and dysfunction of many organs (3) due to high blood glucose level. Several animal studies showed that dental pulp tissue can be affected by diabetes $(5-7,9)$. In this study, we performed an in vitro experiment on the effects of glucose on HDPCs since understanding about oxidative stress and antioxidant system in high glucose condition may be of importance when planning any dental treatment that would depend on the dental pulp response, such as pulp capping, restoration of deep cavities, etc. The glucose concentration of $5.5 \mathrm{mM}$ $(100 \mathrm{mg} / \mathrm{dl})$ was considered as equivalent to normal blood glucose levels, while glucose concentration of $25 \mathrm{~m} \mathrm{M} \mathrm{(450} \mathrm{mg/dl)} \mathrm{was} \mathrm{used}$ to reflect high blood glucose levels (hyperglycemia). The study also used mannitol (Man) as iso-osmolar control to investigate whether these effects were due to osmolarity. In addition, our study was the first to investigate the isoosmolar effects on HDPCs compared to glucose effects.

It was found that no differences were found 
between different treatment conditions during day 1 to day 5. However, the inhibitory effect of $\mathrm{HG}$ on cell proliferation was detected on day 9 and day 11 . In contrast, Okamura et al. (18) reported the positive effects of glucose after HDPCs were cultured in high glucose medium for 2, 4 and 7 days. Kanafi et al. (19) also found that high glucose increased proliferation of HDPCs from both primary and permanent teeth. The difference in the outcome may be because of an individual variation, different method of detection or different percentage of FBS in cultured medium. While our study used MTT assay to imply growth of the cells, a study by Kanafi et al. (19) used cell counting to determine the number of cells. Moreover, our study used 10\% FBS in cultured medium, whereas Kanafi et al. (19) used the medium containing 5\% FBS. FBS contained growth factors, therefore different percentage of FBS may alter the growth of the cells. Nevertheless, our results were consistent with those of Yeh et al. (9), who reported the negative effects of high glucose level on mouse immortalized pre-odontoblastlike cell line (MD10-F2), while iso-osmolar control showed no effects. This may explain why impaired healing and reduction of dentin formation were observed in dental pulp of diabetic individuals $(6,9)$.

DCFH-DA is considered to be an indicator for ROS production, based on the principle that DCFH can further be oxidized to DCF, which gives detectable fluorescence signal (15). In terms of antioxidant defense, GSH is one of the major cellular antioxidants. In the presence of ROS, GSH is oxidized to glutathione disulfide (GSSG) in order to prevent the over accumulation of ROS (20). Our results showed that HG significantly increased ROS production and reduced cellular GSH levels suggesting an imbalance between free radicle formation and antioxidant defense that may lead to cellular damage. Our results were consistent with a previous study from Lee et al. (21) who reported an increase in hydrogen peroxide production after HDPCs were treated with high levels of glucose. However, when $L G, H G$ and Man conditions were supplemented with OI, no differences in ROS levels were found among these three groups. This may be due to the fact that Ol contain ascorbic acid (vitamin C), a well-known antioxidant (22). Vitamin $\mathrm{C}$ was shown to reduce the generation of ROS in HDPCs, therefore effects of glucose were reduced.

Previous studies have explored the effects of glucose on odonto/osteogenic differentiation of HDPCs but the results were still controversial. Okamura et al. (18) demonstrated that high glucose increased odontogenic differentiation of HDPCs. However, a study by Kanafi et al. (19) revealed no differences among glucose concentrations on mineralization of HDPCs. In contrast, Oancea et al. (23) reported low levels of mineral matrix deposit when HDPCs were cultured in high glucose medium which was consistence with our study. HDPCs have been shown to possess the capacity to proliferate and differentiate into hard tissue forming cells $(24,25)$. The controversial results may come from different in the number of progenitors of hard tissue forming cells as well as culture conditions. This study found that mRNA expression of ALP, DSPP, and $\mathrm{ON}$, which are considered as markers for odontoblast and osteoblast differentiation (24), were lower at $\mathrm{HG}$ condition. Furthermore, ARS staining for alizarin red S-calcium complex also confirmed an inhibitory effect of high glucose on odontogenic differentiation of HDPCs. We also investigated the effects of osmolarity on mineral matrix deposit by using Man as iso-osmolar control. The results clearly showed that the inhibitory effects of $\mathrm{HG}$ condition on proliferation and odontogenic differentiation were not due to the change in osmotic pressure since no differences were found between $L G$ and Man conditions.

Our study indicated that high glucose level inhibit proliferation and odontogenic differentiation of HDPCs. In addition, high level of glucose induced ROS production and reduced GSH level. Even though this study is an in vitro study, it confirmed the negative effects of high glucose level on HDPCs suggesting that high glucose level is one of the key factors that contribute to diabetic complication in human dental pulp. The results of this study suggested that the high glucose environment may play a role in healing and regenerative process of dental pulp in diabetic patients.

\section{Resumo}

0 diabetes abrange um grupo de distúrbios metabólicos que podem levar a danos e disfunções de muitos órgãos, incluindo a polpa dentária. Aumento da resposta inflamatória, redução da formação de dentina e comprometimento da cicatrização foram relatados na polpa dentária diabética. A hiperglicemia, que é uma caracteristica determinante do diabetes, desempenha um papel importante em muitas complicações diabéticas. Portanto, nosso objetivo foi investigar os efeitos dos altos niveis de glicose na proliferação, produção de espécies reativas de oxigênio (ROS, em inglês) e diferenciação odontogênica das células da polpa dental humana (HDPCs, em inglês). As HDPCs foram cultivadas em condições de baixa glicose (glicose $5,5 \mathrm{mM}$ ), alta glicose (glicose $25 \mathrm{mM}$ ) e manitol (controle iso-osmolar). A proliferação celular foi analisada pelo ensaio MT por 11 dias. Glutationa e DCFH-DA foram utilizados para avaliar os niveis de ROS e antioxidantes após $24 \mathrm{~h}$ de exposição à glicose. $\mathrm{A}$ diferenciação odontogênica foi avaliada e quantificada pela coloração com vermelho de alizarina no dia 21. A expressão de genes associados à mineralização, que eram fosfatase alcalina, sialofosfoproteína de dentina e osteonectina, foi determinada por RT-qPCR no dia 14. Os resultados mostraram que a alta concentração de glicose diminuiu a proliferação de HDPCs. A diferenciação odontogênica, tanto pela expressão gênica quanto pelo depósito da matriz mineral, foi inibida pela condição de alta glicose. Além disso, altos niveis de DCF e niveis reduzidos de glutationa foram observados na condição de alta glicose. No entanto, não foram observadas diferenças entre o manitol e as condições de baixa glicose. Em conclusão, os resultados mostraram claramente o efeito negativo da condição de alta glicose na proliferação e diferenciação de HDPCs. Além disso, essa condição também induziu a produção de ROS em HDPCs.

\section{Acknowledgements}

The authors thank Dr. Pornrutsami Jintaridh, Faculty of Tropical Medicine, 
Mahidol University for her laboratory support. The project was supported by the Thailand Research Fund through the Royal Golden Jubilee Ph.D. Program (Grant No. PHD/60/2557) to S Horsophonphong and R Surarit.

\section{References}

1. Nanci A. Ten Cate's oral histology: development, structure and function. 7th ed. St. Louis: Mosby/Elsevier; 2008.

2. Smith AJ. Pulpal responses to caries and dental repair. Caries Res 2002;36:223-32.

3. American Diabetes Association. Diagnosis and classification of diabetes mellitus. Diabetes Care 2014;37:s81-s90.

4. Asmat U, Abad K, Ismail K. Diabetes mellitus and oxidative stress-A concise review. Saudi Pharm J 2016;24:547-53.

5. Catanzaro O, Dziubecki D, Lauria LC, Ceron CM, Rodriguez RR. Diabetes and its effects on dental pulp. J Oral Sci 2006;48:195-199.

6. Garber SE, Shabahang S, Escher AP, Torabinejad M. The effect of hyperglycemia on pulpal healing in rats. J endod 2009;35:60-62.

7. Leite MF, Ganzerla $E$, Marques MM, Nicolau J. Diabetes induces metabolic alterations in dental pulp. J endod 2008;34:1211-1214.

8. Russell BG. The dental pulp in diabetes mellitus. Acta Pathol Microbiol Scand 1967;70:319-320.

9. Yeh CK, Harris SE, Mohan S, Horn D, Fajardo $R$, Chun $\mathrm{YH}$, et al. Hyperglycemia and xerostomia are key determinants of tooth decay in type 1 diabetic mice. Lab Invest 2012;92:868-882.

10. Inagaki $Y$, Yoshida $\mathrm{K}$, Ohba $\mathrm{H}$, Seto $\mathrm{H}$, Kido J, Haneji T, et al. High glucose levels increase osteopontin production and pathologic calcification in rat dental pulp tissues. J endod 2010;36:1014-1020.

11. Terada $M$, Inaba $M$, Yano $Y$, Hasuma $T$, Nishizawa $Y$, Morii $H$, et al. Growth-inhibitory effect of a high glucose concentration on osteoblast-like cells. Bone 1998;22:17-23.

12. Wang J, Wang B, Li Y, Wang D, Lingling E, Bai Y, et al. High glucose inhibits osteogenic differentiation through the BMP signaling pathway in bone mesenchymal stem cells in mice. EXCLI J 2013;12:584-597.

13. Gronthos S, Arthur A, Bartold PM, Shi S. A method to isolate and culture expand human dental pulp stem cells. Methods Mol Biol 2011;698:107-121.

14. Mosmann T. Rapid colorimetric assay for cellular growth and survival: application to proliferation and cytotoxicity assays. J Immunol
Methods 1983;65:55-63.

15. Kalyanaraman B, Darley-Usmar V, Davies KJA, Dennery PA, Forman HJ, Grisham MB, et al. Measuring reactive oxygen and nitrogen species with fluorescent probes: challenges and limitations. Free Radic Biol Med 2012;52:1-6.

16. Gregory CA, Gunn WG, Peister A, Prockop DJ. An Alizarin red-based assay of mineralization by adherent cells in culture: comparison with cetylpyridinium chloride extraction. Anal Biochem 2004;329:77-84.

17. Cooper PR, Holder MJ, Smith AJ. Inflammation and regeneration in the dentin-pulp complex: a double-edged sword. J endod 2014;40:S46-51.

18. Okamura T, Nishikawa T, Tanaka A. Calcification on cultured human dental pulp cells exposed to high glucose level. Oral Med Pathol 2009;13:47-53.

19. Kanafi MM, Ramesh A, Gupta PK, Bhonde RR. Influence of hypoxia, high glucose, and low serum on the growth kinetics of mesenchymal stem cells from deciduous and permanent teeth. Cells Tissues Organs 2013;198:198-208

20. Lu SC. Regulation of glutathione synthesis. Mol Aspects Med 2009;30:42-59.

21. Lee YH, Kim GE, Song YB, Paudel U, Lee NH, Yun BS, et al. Davallialactone reduces inflammation and repairs dentinogenesis on glucose oxidaseinduced stress in dental pulp cells. J Endod 2013;39:1401-1406.

22. Bendich A, Machlin $\sqcup$, Scandurra O, Burton GW, Wayner DDM. The antioxidant role of vitamin C. Adv Free Radicals Biol Med 1986;2:419444.

23. Oancea R, Deak E, Popovicil A, Iliuta L, Sava-Rosianu R. Behavioural changes and plastic potential alteration of dental pulp stem cells exposed to high glucose concentrations. Dig J Nanomater Biostruct 2013;8:313-321.

24. Gronthos S, Brahim J, Li W, Fisher LW, Cherman N, Boyde A, et al. Stem cell properties of human dental pulp stem cells. J Dent Res 2002;81:531-535.

25. Hosoya $A$, Nakamura $H$. Ability of stem and progenitor cells in the dental pulp to form hard tissue. Jpn Dent Sci Rev 2015;51:75-83.

Received December 17, 2019 Accepted June 5, 2020 